\title{
Water Technology in the Paper Industry in the Valley of Mexican Basin
}

\author{
Lilia Rodríguez-Tapia $^{1}$ (D) $\cdot$ Marina Pedro-Aburto $^{2} \cdot$ Jorge A. Morales-Novelo $^{1}$ (D) $\cdot$ Daniel A. Revollo-Fernández ${ }^{1}$ (D)
}

Received: 7 November 2019 / Revised: 14 February 2020 / Accepted: 18 February 2020 / Published online: 17 March 2020

(C) The Author(s) 2020

\begin{abstract}
This article identifies the technological characteristics of the paper manufacturing industry in the Valley of Mexican Basin (VMB) - a densely populated region characterized by absolute water scarcity —in order to quantify the intensity with which water is used. The method consisted of modeling the paper industry's technology estimating Cobb-Douglas production functions at two moments in time. The comparison of both functions makes it possible to identify water saving technologies during this period, and to evaluate whether the industry has made adjustments to deal with water restrictions. The data is obtained from the Economic Censuses of the National Institute of Statistics Geography and Informatics 2009 and 2014. While our work must be considered preliminary owing to the somewhat irregular nature of the data, certain clear conclusions do stand out. The paper industry located in the VMB has drastically reduced its water usage during the period of time analyzed. This is explained by the adoption of water saving technologies in the industry. In the process, an increase in capital is the main variable to explain such a technical change. This is expressed in the manner in which water and capital inputs appear to be highly suitable substitutes in paper manufacturing.
\end{abstract}

Keywords Technology $\cdot$ Water saving $\cdot$ Paper industry $\cdot$ Production function $\cdot$ Cobb-Douglas function

\section{Introduction}

The economics of production is concerned with choosing between alternative technologies to produce a commodity or service. The optimal combination of resources is a key aspect in any production process whether at the business or industry level. The technological choices are influenced by the

Lilia Rodríguez-Tapia

lrt@azc.uam.mx

Marina Pedro-Aburto

marinapedro1@gmail.com

Jorge A. Morales-Novelo

jamn@azc.uam.mx

Daniel A. Revollo-Fernández

darevollof@conacyt.mx

1 Department of Economics, Autonomous Metropolitan University, Azcapotzalco Campus, Av. San Pablo No. 180, Col. Reynosa Tamaulipas, Azcapotzalco, C.P. 02200 Mexico City, Mexico

2 Environment and Sanitary Division, Autonomous National University of Mexico, Av. Universidad 3000, Ciudad Universitaria, Coyoacán, CP 04510 Mexico City, Mexico changing circumstances of technological or economic innovations [1]. In the same way, the state of the natural resources that supply industries is also critical to production. This is made more evident as the scarcity or decay of such resources is increased [2]. Starting from the pioneering work of Grebenstein and Field [3] who made research on the substitution for water inputs in US manufacturing and point out that "As such, the study represents another step-in analytical thrust that has gained some popularity in recent years: the econometric investigation of aggregate production functions containing natural resources." From then onwards, many studies have been presented on production functions of several natural resources as noted by Babin et al. [4]: "Berndt and Wood, 1975; Berndt and Jorgenson, 1973; Griffin and Gregory, 1976; Humphrey and Moroney, 1975; Moroney and Toevs, 1977'.

Despite the importance of industrial water use and the features that distinguish it from other types of water use, the role of water in industrial applications remains a remarkably understudied area $[5,6]$. This statement is pertinent to the case of Mexico where research on the topic is scarce.

Given that production processes are notably complex, the disciplines of economics and industrial engineering have found it useful to employ deductive abstract reasoning to 
formulate theories regarding the decisions made by businesses or industries. The theories are simplified and generalized representations of reality. Since they are generalizations of specific cases, there are elements of events that are shared. The theory serves to interpret and guide empirical studies.

The production technology of an industry can be modeled in three different ways: (i) the production function; (ii) profit function; and (iii) cost function [7]). Our approach to modeling production processes departs from earlier studies which use production functions. The forms of production functions that have been transcendent in the modeling of production are Cobb-Douglas function in 1928 [8], the Leontief function in 1941 [9], and the Constant Elasticity of Substitution function (CES) in 1961 [10]. Only a few mathematical forms of production functions are commonly used in textbooks. Besides the named before, there are quadratic [11]) and transcendental [12]). New functional forms have been created in the estimation of production models, Mitscherlich, Spillman, resistance, modified resistance [13]; square roots [14]; translogarithmic [15]; generalized Box-Cox [16]; and augmented Fourier [17].

In the empirical estimation, choosing the functional form of the production function implies selecting a specification that allows the analysis of the hypotheses without imposing a priori restrictions. As Fuss, McFadden, and Mundlak [18] have pointed out, choosing a functional form determines that some hypotheses cannot be verified. Nevertheless, one must be aware of the properties of alternative production function specifications. This is to know the technical and economic implications of a particular functional form, and to know what one might be forcing on the data in empirical applications. General function forms are usually difficult to manipulate mathematically (often not amenable to analytic solutions) and pose statistical problems. However, they are quite often justified by the increased precision allowed by the general forms [1].

The production process in the paper industry comprises three stages. The first is the production of cellulose pulp made from woodchips or from recycled materials. The second is treating the cellulose mechanically and chemically in order to give it specific characteristics such as thickness, strength, and whiteness, and finally the cellulose pulp is compressed and dried to form paper sheets [19].

In the paper industry, both technological changes, as well as the need for a better quality product, have had a significant impact in water usage. During the last century, the improvement in paper quality increased its water usage. Blair T. Bower [20] cites a research paper from the paper industry done by Knowlton in 1964 for the USA in which he estimates an increase in the quantity of water used in the pulp and paper industry during a 5-year period, from 1954 to 1959 . During this period, the quantity of water used to produce one ton of paper was increased by almost $13 \%$-from 42.2 to $47.5 \mathrm{~m}^{3}$. The paper industry is one of the most important industries of the North American economy and ranks as the fifth largest in the US economy; as stated by Nemerow and Dasgupta [21], between 20,000 and 60,000 gal of water per ton of product are utilized in the industry in 1991. Bower [20] describes based on evidence in other research papers that this trend continued until 2002, an increase that is explained by the remarkably higher standards in the quality of the final product, more sophisticated products and new colors. As a counterpoint, technological changes have been made to reduce the quantity of water used by the paper industry in this century. However, the production of paper from the pulp and the productive processes of the paper industries require substantial amounts of fresh water, $10-110 \mathrm{~m}^{3}$ per ton of product [22].

The industry's water consumption is most commonly measured through its extraction of ground water bodies; however, as Renzetti points out in the introduction of his book The Economics of Industrial Water Use [5], there is a broad range of approaches taken to model the role of water in the industry: "Several researchers (Rees, 1969; Turnovsky, 1969; Grebestein and Field, 1979; Babin, Willis and Allen, 1982) have chosen to include only the amount of water incorporated (intake). Simis (1979) includes the amounts of water incorporated as well as the amount of emissions (bio-oxygen demand (BOD) and suspended solids (SS)). Renzetti (1992, 1993) and Dupont and Renzetti (1998) include four separate stages for the use of water: incorporated water, recycled water, treatment of water before use, and water discharge. Dupont and Renzetti (2001) include water incorporated and recycled water as separate inputs." In this paper, the production function is estimated in order to measure the impact of technology in the amount of water incorporated during production.

Similarly, in Mexico, the paper industry also presents a high-water consumption, as it will be displayed in this study. The paper industry requires great volumes of water to be extracted from the region where it is located.

Since this VMB region is characterized by an absolute shortage of water resources, this study aims to identify the impact of this restriction on the technological characteristics of the papermaking industry in the VMB, to quantify the intensity of water use. The hypothesis underlying this study is that the extreme stress that exists in the region has led to significant water savings in the industry. The method consisted of modeling the paper industry's technology estimating Cobb-Douglas production functions at two moments in time. The comparison of both functions makes it possible to identify water saving technologies during this period, and to evaluate whether the industry has made adjustments to deal with water restrictions. The production function of the paper industry in the VMB is estimated within the framework of the Cobb-Douglas function, which could potentially be a good approximation for production processes. Research takes place in 2008 and in 2013; comparison of both settings enables an assessment on the inclusion of water saving technologies during this period. 
The contribution of this research consists in estimating the production function of the paper industry in a specific region of Mexico. This is because the literature on similar research and methodology on this industry is highly limited. Consequently, this study seeks to provide more data that will allow us to measure technological progress in an efficient use of water resources in paper industry in various parts of the world. Besides, the results show that this methodology let to know the technology advance in a specific industry.

In addition to the introduction, this paper is comprised of the following four sections: "Background," "Method," "Results," and "Conclusions."

\section{Background}

\section{Absolute Scarcity of Water in the Valley of Mexican Basin}

The VMB is Mexico's most densely populated region, with 22 million inhabitants, making this one of the densest populations in the world. In this region, approximately $31.3 \%$ of the national Gross Domestic Product is generated.

In 2015 , water demand per capita was $155.5 \mathrm{~m}^{3} /$ year, which is well above the $89.8 \mathrm{~m}^{3} /$ year of renewable water captured in the basin (Natural Media Availability, NMA) [23]. This excessive extraction over and above the NMA is explained by the overexploitation of aquifers in the basin $\left(36.2 \mathrm{~m}^{3} /\right.$ year) and the importation of water from other basins $\left(29.4 \mathrm{~m}^{3} /\right.$ year). The Relative Water Stress Index (RWSI), which links the total volume of water allotted through concessions and the NMA of the water (multiplied by 100), is $140.4 \%$ for the VMB, making it one of the regions with the greatest pressure on its water resources, along with Yemen and the United Arab Emirates [24].

In this context of extreme water stress, it is imperative to adopt policies that ensure that the various uses of water in the basin are efficient. In particular, industrial use is important because the manufacturing industry plays a key role in the dynamics of the economic activity of the VMB. It accounts for one-fifth of the basin's Gross Domestic Product, generates employment as well as goods and services to be consumed by the people in the region, and exports outside the basin and the country.

Water is an essential resource for the production processes that are carried out by industries located in the basin. In 2015 only, they used approximately 127 million $\mathrm{m}^{3}$ for those processes, which is $10.1 \%$ of the water used by the industry nationwide [25]. The manufacturing industry extracts most of the water from aquifers, which are currently so overexploited that most of them have been declared in permanent closure. With a reported null availability of the resource, further exploitation would cause them irreversible damage. In addition, to complement its water needs, industry uses water from the urban public supply, which also mainly comes from external aquifers, and has the same adverse impacts on those bodies of water [24].

Despite the high levels of water stress in the valley, the demand for industrial water grows, increasing the pressure on the aquifers, which is of concern for all users of the resource in the region.

\section{Modeling the Industrial Use of Water}

The industry's water usage is responsive to diverse forces. The most important of these forces is the technology involved in the processes, followed by economic forces such as input costs, charges, taxes, tariffs, and level of production. Technological changes within the businesses are the driving force in reducing first time water usage: the internal recirculation of water, consumption of new materials, and so forth [20].

According to Bower [20], the basic observations to consider when researching water usage in the industry are:

Water is a single factor, among others, of the production process and must be analyzed as such. Therefore, the research must be done within the context of the other inputs.

Technological changes have varied and substantial impacts in the way that the industry uses water. The changes that affect other inputs can have a positive or a negative effect in the industry's water usage.

Problems for each industry or plant are unique due to their particular situation.

Criterion used by the industry to assess investments that save water is the return rate on the investment.

Furthermore, restrictions on businesses must be considered. These can be internal such as a limited budget, the quality of the product, the technology currently available, and external restrictions such as limited sources of water and particularly physical limitations, either in quantity or quality.

One approach that includes such recommendations is attempting to study the structure of production. To do this, a production function must be estimated. The production of any good or service requires a combination of resources, such as equipment, labor, management, capital, space, and natural resources, among others. Together, these contribute to the total output.

A production function relates the production (as a dependent variable) and the quantities of the various components of production (as independent variables) [26]. Considering that $Q$ is the product of the industry (measured in physical units) and $x_{i}$ are the quantities of all the supplies, the industrial 
process is simplified in one mathematical function that captures the main variables of the process.

$Q=f\left(x_{1}, x_{2}, x_{3}, \ldots x_{n}\right)$

The traditional approach used by industrial engineering is the specification of the function of production in a linear equation, where the production is the result of the sum of all of the inputs used.

$Q=\alpha_{1} x_{1}+\alpha_{2} x_{2}+\alpha_{3} x_{3}+\ldots \alpha_{n} x_{n}$

In this equation, the coefficients $\alpha_{1}, \alpha_{2}, \alpha_{3}, \ldots \alpha_{n}$ represent fixed proportions of each of the inputs required to produce one unit of product. By not allowing modifications, they represent a technology that is rigid; any level of production is proportional to the coefficients. Additionally, this function presents limitations when interpreting and comparing basic concepts of production since it registers a recurrent marginal product for each variable; the elasticity between the production and the supplies is variable in each level of production. This makes it unmanageable to compare the model to other production scenarios [26].

The abovementioned limitations are overcome through a non-linear production function, which must be interpreted as a complementary model to the linear programming. In the field of economics, there is a large body of literature on how to estimate production functions. The non-linear functions generally used are Cobb-Douglas, quadratic, constant elasticity of substitution, transcendental [1], and translogarithmic [6]. These functions simulate to varying degrees flexible technologies that allow for the substitution between the supplies that form part of the production of a good or service. In addition, they simulate a decreasing marginal productivity, and elasticity between the production and the recurrent inputs, which allows for it to be compared to different scenarios.

For a given sample of industrial facilities, there is usually little theoretical justification for selecting one of the general functional forms postulated for production relationships [27].

\section{Method}

The discipline of industrial engineering and the neoclassical theory of production provide a meaningful scheme of representing the industry's sensitivity to water usage. This is achieved by representing water as an independent input within the function of production. This paper is framed under the engineering perspective that intends to record the technical aspects of production, which is why the costs of inputs and production are considered to be fixed and as such do not alter it.

The method consists of defining the function of production base in order to model the paper industry's production and its technological properties; that is, specifying in one equation the process of production in such a way that its parameters capture the most relevant characteristics of the technology being used [1]. Secondly, two functions of production are calculated based on the data of the industry in two moments in time. Thirdly, the results are analyzed and compared. The comparison of the parameters of both functions describes the technological change in the industry; water usage is of particular interest (Fig. 1).

\section{Cobb-Douglas Function}

The basic inputs required to make paper are wood, water, chemicals, workers, and machinery among others. The use of water during the different stages of the process is highlighted. All the factors present in the productive process are classified in 4 groups denominated factors of production: labor $(L)$, raw and secondary materials $(M)$, water $(W)$, and capital (K) [26].

The Cobb-Douglas function in its most general form relates the production $(Q)$ to the factors of production $(L, M, K, W)$.

$Q=A L^{\alpha \mathrm{L}} M^{\alpha \mathrm{M}} W^{\alpha \mathrm{W}} K^{\alpha \mathrm{K}}$

The origin of the work on production functions can partly be attributed to the works of Cobb and Douglas [8], who suggested the existence of laws of production governing the proportion of productive factors. The actual distribution of output into factors was consistent with estimated values of their parameters, and thus the productive factors received their marginal values. The Cobb-Douglas production function has

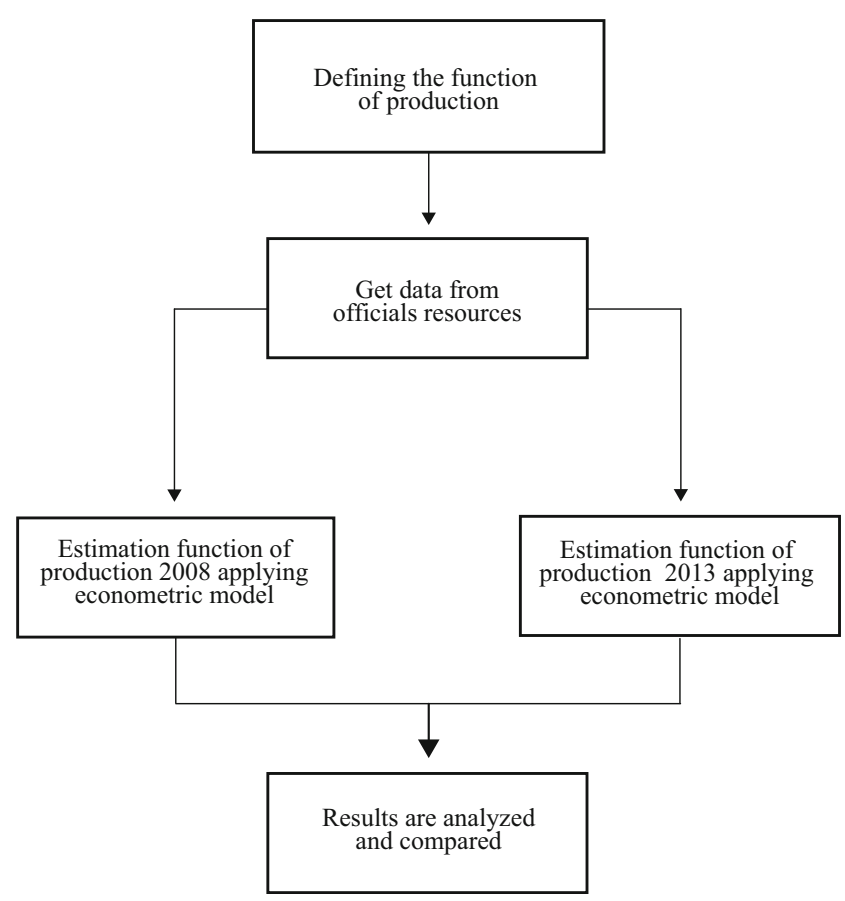

Fig. 1 Flowchart of methodology 
been widely used in the empirical analyses of production functions. However, there are important limitations associated with this function partly due to assumptions of additivity and homogeneity, restricted by a unitary constant elasticity of substitution.

This approach is valuable since its methodology enables recovering factor elasticities $\left(\alpha_{\mathrm{s}}\right)$, returns to scale (constant $A$, associated to technology), and a rate of technical substitution of one factor to another (RTS). Such parameters note the technological structure of the industry. These parameters allow the identification of, in particular, the relationship between the inputs and the product, as well as the relationship between inputs, highlighting the technical relationship without allowing for the influence of economic variables such as costs.

The Cobb-Douglas may be a good approximation for production processes for which factors are imperfect substitutes. It is also relatively easy to estimate because it is parsimonious in parameters, and in logarithmic form, it is linear in the parameters [1].

\section{Data}

Data was obtained from the National Directory of Statistics and Economic Units (DENUE in its Spanish acronym) [28] and from the Economic Censuses 2009 and 2014 of the National Institute of Statistics Geography and Informatics (INEGI in its Spanish acronym) [29, 30]. The number of paper production economic units (EU) in the VMB was obtained from DENUE, which was cross-checked with the Economic Censuses.

Data regarding production, raw materials and capital expressed in monetary units, number of workers, and water incorporated into the production in $\mathrm{m}^{3}$ was obtained from the latter source. Ideally, all the variables should be in physical units. Since this is not possible, the monetary aggregates are worked a constant prices. Additionally, it must be noted that, during the time researched, the change in prices was less than $10 \%$ so the estimated parameters in the functions of production were not affected in any significant way.

The databases on the value of production and on the elements of production were construed based on the Economic Census 2014 (data from 2013) [30] and 2009 (data from 2008) [29]. Even though in the Economic Censuses the data is registered at the level of economic unit, due to confidentiality reasons, it is not possible to process it at this level so the data is added at the municipal level (on the assumption of constant returns).

The database from 2008 consists of 32 observations and the one from 2013 of 34, adequate for the Cobb-Douglas function.

\section{Results}

\section{Estimates for the 2008 Model}

\section{Accuracy of the Results}

Table 1 presents the parameters of the 2008 model. The value of the correlation between the variables $\left(R^{2}\right)$ is 0.95 , which indicates the existence of a very good correlation between the dependent variable and the independent variables in the model.

From the estimated parameters, two present a greater statistical significance, which are $\alpha_{w}$ with a confidence of $99 \%$ and $\alpha_{M}$ with a confidence of $95 \%$. The parameters with $90 \%$ significance are $\alpha_{L}, \alpha_{k}$, and $\operatorname{Ln} \mathrm{A}$.

The production function estimated in its exponential form is:

$Q=61.55 L^{0.20} M^{0.16} \mathrm{~W}^{0.58} K^{0.06}$

\section{Estimates for the 2013 Model}

\section{Accuracy of the Results}

Table 2 presents the parameters of the 2013 model. The model gives a $R^{2}$ of 0.92 , which means that there is a correlation of $92 \%$ between the dependent variable $(\mathrm{Q})$ and the independent variables.

In the 2013 model, the variable that has the greatest statistical significance is the elasticity $\left(\alpha_{\mathrm{s}}\right)$ for the variables $\mathrm{W}$ and $\mathrm{M}$ and LnA with a confidence of $99 \%$. For this model, the parameters that have the lesser significance are those relating to the variables $\mathrm{K}$ and $\mathrm{L}$.

From these results, the Cobb-Douglas equation has the following exponential form:

$Q=249.63 L^{0.21} M^{0.34} W^{0.25} K^{0.20}$

The 2008 function is slightly more robust than that from 2013. However, the significance of both models is good; thus, it is pertinent to make a comparative analysis.

\section{Model Comparison}

The paper industry in the VMB grew considerably from 2008 to 2013 (its growth rate was above the paper industry's production index in Mexico which was greater than 13\% [31]), 172 new enterprises emerged, fresh water consumption increased by $384,621 \mathrm{~m}^{3}$, and employment rose with 11,100 new workers added to the workforce $[29,30]$.

The production functions estimated in the VMB for the years 2008 and 2013 note important changes in the technology used during the production, as can be appreciated comparing equations 4 and 5 . 
Table 1 Estimated parameters for the 2008 model

\begin{tabular}{lllllll}
\hline Parameters & Estimator & Standard deviation & Statistical $t$ & $p$ value & Significance & $R^{2}$ \\
\hline Ln A & 4.124 & 1.536 & 2.685 & 0.0123 & $* *$ & 0.95 \\
$\alpha_{\mathrm{L}}$ & 0.200 & 0.230 & 0.892 & 0.3802 & & \\
$\alpha_{\mathrm{M}}$ & 0.160 & 0.069 & 2.324 & 0.0279 & $* *$ & \\
$\alpha_{\mathrm{W}}$ & 0.580 & 0.149 & 3.890 & 0.0006 & $* * *$ & \\
$\alpha_{\mathrm{k}}$ & 0.060 & 0.072 & 0.907 & 0.3720 & & \\
$\alpha_{\text {Total }}$ & 1.000 & & & & & \\
\hline
\end{tabular}

Statistical significance: $*=10 \%, * *=5 \% * * *=1 \%$

\section{Increasing Returns to Scale in the Paper Industry}

Parameter $A$, which measures the total productivity of the factors, is greater than one for both functions. This shows that technology in the VBM's paper industry is characterized by recording increasing returns to scale. In 2008, the value of parameter $A$ is 61.55 and for 2013 it increased to 249.63 Mexican pesos. This increase is recorded in real terms if we consider that the national index in prices to the producer decreased by $3 \%$ in this same period [32]. This means that with the same amount of water, raw materials, labor, and capital, the industry produced a volume of goods three times larger in 2013 than in 2008 . In only 5 years, an impressive increase was recorded in the productive capabilities of the paper industry in the VBM. This result suggests that one of the main causes of the productive increase was the technological change incorporated to the process and to the management of businesses, which allowed for a better use of each and every one of the resources. In this work, it is important to highlight the technical changes, specifically in the use of water, which are described below.

\section{Elasticity Between Production and Water}

The paper industry reduced water consumption by product unit in the period from 2008 to 2013. In 2008, elasticity between production and water was 0.58 and in 2013 this value was reduced to 0.25 . This means that the sensitivity of the paper industry to the use of water was reduced in an impressive manner. A $10 \%$ increase in water use had a $5.8 \%$ impact on production in 2008 and only a $2.5 \%$ impact by 2013 , practically reduced by half. This shows the clear transformation of the paper industry to be less intensive in its use of water.

Reduction in the elasticity of water is compensated by an increase in the elasticity of capital and raw materials. Elasticity between production and capital $\left(\alpha_{k}\right)$ was tripled from 0.06 to 0.20 , due to new machinery being incorporated in the industry, including wastewater treatment plants, filters, the implementation of recycling systems, and new water recirculation systems.

The increase in elasticity between production and raw and secondary materials $\left(\alpha_{M}\right)$ went from 0.16 to 0.34 ; it duplicated, which describes an increase in the sensitivity of the production to the use of different and new raw and secondary materials.

Elasticity between production and labor $\left(\alpha_{L}\right)$ remained virtually unchanged, meaning that it maintains its importance in the industry. This shows that in the process of incorporating new technologies to the paper manufacturing industry, labor has not been displaced and that workers have probably been retrained to help them adapt to the new circumstances gained from the economies of scale.

\section{Marginal Rate of Substitution Between Water and the Factors of Production}

The Cobb-Douglas function entails a unitary elasticity of substitution between factors, which indicated that there is substitution between them (excluding the possibility of complementarity). This property simulates a flexible technology in the paper
Table 2 Estimated parameters for the 2013 model

\begin{tabular}{lllllll}
\hline Parameters & Estimator & Standard deviation & Statistical $t$ & $p$ value & Significance & $R^{2}$ \\
\hline Ln A & 5.522 & 1.292 & 4.271 & 0.0002 & $* * *$ & 0.92 \\
$\alpha_{\mathrm{L}}$ & 0.208 & 0.178 & 1.168 & 0.2524 & & \\
$\alpha_{\mathrm{M}}$ & 0.345 & 0.094 & 3.640 & 0.0011 & $* * *$ & \\
$\alpha_{\mathrm{W}}$ & 0.249 & 0.089 & 2.779 & 0.0095 & $* * *$ & \\
$\alpha_{\mathrm{K}}$ & 0.198 & 0.133 & 1.486 & 0.1482 & & \\
$\alpha_{\text {Total }}$ & 1.000 & & & & & \\
\hline
\end{tabular}

Statistical significance: $*=10 \%, * *=5 \% * * *=1 \%$ 
Table 3 Technical marginal rate of substitution between water and other factors of production 2008 and 2013

\begin{tabular}{lllll}
\hline MRS & 2008 & 2013 & Absolute change & Percentage change (\%) \\
\hline L/W & -2.90 & -1.19 & -1.71 & -58.96 \\
M/W & -3.60 & -0.73 & -2.87 & -79.72 \\
K/W & -9.67 & -1.25 & -8.42 & -87.73 \\
\hline
\end{tabular}

industry by allowing for technical substitution between the same factors.

In this section, the technical marginal rates of substitution (MRS) between water and the other factors are compared in the two estimated production functions.

The MRS between water and other factors is presented in Table 3 .

Table 3 shows that, in 5 years, the paper industry increased its capacity to substitute water for any of the other factors of production, meaning that the same amount of water is substituted for a lesser amount of the other factors. That the amount decreased by every factor in order to substitute one $\mathrm{m}^{3}$ of water is indicated in column three, and in column 4 the percentage into which this reduction is translated. Capital is the factor that reduced by most its quantity required, $87 \%$, followed by materials with a reduction of almost $80 \%$, and, in last place, labor with a reduction of $41 \%$. This behavior of the industry indicates that from a technical point of view, it is convenient to substitute water for other production factors. It is then observed that the paper industry is using less water and that its technology is more flexible to saving water.

\section{Conclusions}

The Cobb-Douglas function is an adequate way of modeling the production function of the paper industry in the BMV since it captures the most important features of technology. Furthermore, the production functions estimated for 2008 and 2013 are robust.

The analysis and comparison of these production functions allow the assertion that the underlying hypothesis of this paper is met, that the technological changes in the industry are a response, to some extent, to the high levels of water stress recorded in the BMV.

While our work must be considered preliminary, owing to the somewhat irregular nature of the data, certain clear conclusions do stand out. The paper industry located in the VMB has drastically reduced its water usage during the period of time analyzed. This is explained by the adoption of water saving technologies in the industry. In this process, the increase of capital is the main variable to explain such a technical change. This is expressed by the observation that water and capital inputs appear to be highly suitable substitutes in the paper manufacturing.

In only 5 years (2008-2013), the paper industry in the VMB has made significant technological changes that have led to an increase in its productivity. A technological change was recorded in the years between the two estimated production functions. This was reflected by a tripling of the overall returns of the factors. The value of the constant $A$ went from 61.55 to 249.63 Mexican pesos in the corresponding production functions, indicating that an increase returns to scale is a structural characteristic of this industry.

In 2013, the paper manufacturing industry relied less on water use and more on capital, raw materials, and labor. These last factors have an importance in the above order. During the period researched, elasticity between production and water fell. In 2008, elasticity was 0.58 , which indicates that in the face of a $10 \%$ increase in water use, paper production increased by $5.8 \%$, which shows the elevated sensitivity to water use. By 2013, its elasticity was 0.24 and indicates that, in the face of a similar increase in the use of water, there is an impact in the production of paper of $2.4 \%$, showing that sensitivity to water use was reduced in half.

During the process of this research, we did not find any papers that would allow for us to contrast our results, so we compared them with other regions. In 1993, Wang and Lall [6] researched the use of water in the manufacturing industry of China and concluded that, in the paper industry, product elasticity of water is 0.10 , a value that is lower than the elasticity in the VMB. Research performed by Vargas Ovando [33] in his doctoral thesis in 2015 on the use of water in the manufacturing industry of Chile reported that the paper industry presents elasticity between the production and water of 0.025 , a value that is lower than the two above indicated papers. The comparison in elasticities shows that, even if there is a clear trend to reduce water use in the paper industry in the VMB, a significant gap remains in order to reach values closer to international standards.

The technological changes incorporated in the paper industry in the VMB have allowed for the substitution of water with other production factors. The marginal rates of substitution between water and the other production factors describe such a process. It highlights the reduction of water use by substituting it for more efficient machinery. In second place, there is the substitution of water for materials that allow for the recovery of water through the treatment of wastewater. This last effect is becoming more relevant worldwide. The leading countries in new technologies in the paper industry (Finland, Denmark, Sweden) are developing technological changes to save water, recovering it during the bleaching process through the use of chemicals. The recovery takes place through closed circuits in specific processes so that no water is discharged. Another measure that allows for a reduction in water consumption is by improving integrated treatment in the paper 
manufacturing process and by developing systems that capture gases, oxidation of contaminating chemicals, and systems of recirculation [19].

All of the analyzed parameters in the estimated production functions indicate that the paper industry in the VMB tends to save more water, which shows it is adapting to the restrictions it faces due to it being located in a region with absolute water scarcity. Another aspect that contributes to this process is that the first stage in the paper manufacturing process - the manufacturing of cellulose-does not take place in the VMB. However, the cellulose used has to be hydrated, which demands a significant amount of water.

The model of production based on the Cobb-Douglas function captures the most relevant features of the paper manufacturing industry's technology and points out the importance of doing more empirical research on conditions and regions specific to Mexico.

The most important implication of this research is that an external factor in the paper industry - such as the absolute water scarcity in the VMB - has led it to incorporate more efficient technology in order to remain located in the region that is its biggest market. This research suggests that there is an inverse relationship between increased scarcity of water and a decrease in the quantity of water incorporated in the unitary production of paper.

In addition to technological improvements, public policy regarding efficient public management of scarce water resources in the VMB must consider the cost of water and the control of effluents.

Funding Information This work was supported by Mexico's National Council of Science and Technology (CONACYT in Spanish) under Marina Pedro Aburto through the grant obtained to research the paper industry as part of the Postgraduate Degree on Engineering and Environmental Sciences during the period from September 2016 to August 2018 and by Daniel A. Revollo-Fernández through the Young Researches Support Program, project number 1812.

Open Access This article is licensed under a Creative Commons Attribution 4.0 International License, which permits use, sharing, adaptation, distribution and reproduction in any medium or format, as long as you give appropriate credit to the original author(s) and the source, provide a link to the Creative Commons licence, and indicate if changes were made. The images or other third party material in this article are included in the article's Creative Commons licence, unless indicated otherwise in a credit line to the material. If material is not included in the article's Creative Commons licence and your intended use is not permitted by statutory regulation or exceeds the permitted use, you will need to obtain permission directly from the copyright holder. To view a copy of this licence, visit http://creativecommons.org/licenses/by/4.0/.

\section{References}

1. Beattie BR, Taylor CR, Watts MJ (2009) The economics of production, 2nd edn. Krieger Publishing Company, Malabar
2. Field BC, Field MK (2003) Economía Ambiental, 3rd edn. McGraw-Hill/Interamericana de España, S.A.U, Madrid

3. Grebenstein CR, Field BC (1979) Substituting for water inputs in US manufacturing. In: Water resources research 15(2). American Geophysical Union, USA

4. Babin FG, Willis CE Allen GP (1982) Estimation of substitution possibilities between water and other production inputs. In: American journal of agricultural economics 64(1). Oxford University Press on behalf of the Agricultural and Applied Economics Association, UK

5. Renzetti, S. (2002). Introduction. In S. Renzetti. (Ed.). The economics of industrial water use. USA: Edward Elgar Publishing Limited

6. Wang H, Lall S (2002) Valuing water for Chinese industries: a marginal productivity analysis. In: In Applied Economics 34 (6). Taylor and Francis Group., London. https://doi.org/10.1080/ 00036840110054044

7. Kumar, S. (2004). Analyzing industrial water demand in India: an input distance function approach. In National Institute of Public Finance and Policy working paper no. 12/2004. Available at SSRN: https://doi.org/10.2139/ssrn.552441

8. Cobb CW, Douglas PH (1928) A theory of production. Am Econ Rev 18:139-165

9. Leontief, W. (1941) The structure of the American economy: 19191939, an empirical application of equilibrium analysis. Harvard University Press.

10. Arrow K, Chenery H, Minhas B, Solow RM (1961) Capital-labour substitution and economic efficiency. Rev Econ Stat 43(3):225-250

11. Denny M (1974) The relationship between forms for the production system. In: The canadian journal of economics, 7(1):21-31. John Wiley and Sons on behalf of the Canadian Economics Association, New Jersey. https://www.jstor.org/stable/134212

12. Halter A, Carter H, Hocking J (1957) A note on the transcendental production function. Am J Agric Econ 39:966-974

13. Heady E, Dillon J (1961) Agricultural production functions. Am J Agric Econ 43(4). Ames: Iowa State University Press):978-979. https://doi.org/10.2307/1236037

14. Lau LJ (1978) Testing and imposing monotonicity, convexity and quasi-convexity constraints. In: Fuss M, McFadden D (eds) Production economics: a dual approach to theory and applications. North-Holland Publishing Co., Amsterdam, pp 409-453

15. Christensen LR, Jorgenson DW, Lau LJ (1973) Transcendental logarithmic production frontiers. Rev Econ Stat 5:528-545

16. Berndt ER, Khaled MS (1979) Parametric productivity measurement and choice among flexible functional forms. J Polit Econ 87(6):1220-1245

17. Chalfant J, Gallant A (1985) Estimating substitution elasticities with the Fourier costs function, some Monte Carlo results. J Econ 28. North-Holland:205-222

18. Fuss M, McFadden D, Mundlak Y (1978) A survey of functional forms in the economic analysis of production. In: Fuss M, McFadden D (eds) Production economics: a dual approach to theory and applications. North-Holland Publishing Co., Amsterdam, pp 219-268

19. Bajpal P (2010) Environmentally friendly production of pulp and paper. John Wiley \& Sons, Inc.

20. Bower, B. T. (1966). The Economics of industrial water utilization. In S. Renzetti. (Ed.). The Economics of Industrial Water Use. USA: Edward Elgar Publishing Limited

21. Nemerow NL, Dasgupta A (1991) Industrial and hazardous waste treatment. In: Environmental Engineering Series. Van Nostrand Reinhold. Kennesaw, New York

22. Anushree A, Kumar S, Sharma C (2016) Ce1-xCoxOy nanocatalysts: synthesis, characterization and environmental application. Catalysis Science \& Technology 6:2101-2111

23. Comisión Nacional del Agua (CONAGUA) (2015) Programa Hídrico Regional, Región Hidrológico-administrativa XIII Aguas 
del Valle de México. Recuperado el el 23 de julio de 2019 de https://agua.org.mx/wp-content/uploads/2015/09/Estadisticas_ Agua_Valle_de_Mexico_2014.pdf

24. Revollo-Fernández D, Rodríguez-Tapia L, Morales-Novelo J (2019) Economic value of water in the manufacturing industry located in the Valley of Mexico Basin. In: Water, Resources and Economics. Elsevier, Mexico. https://doi.org/10.1016/j.wre.2019.01.004

25. Comisión Nacional del Agua (CONAGUA) (2016) Estadísticas del Agua en México (ed. 2016). Recuperado el 2 de julio 2019 de: http://201.116.60.25/publicaciones/EAM_2016.pdf

26. Varian HR (2014) Intermediate microeconomics: a modern approach, 9th edn. W. W. Norton \& Company, Inc.

27. Stone JC, Whittington D (1984) Industrial water demand. In: Renzetti S (ed) The economics of industrial water use. Edward Elgar publishing limited

28. Instituto Nacional de Estadística, Geografía e Informática (INEGI) (2018) Directorio Estadístico Nacional de Unidades Económicas. Recuperado el 4 de marzo de 2018, de https://www.inegi.org.mx/ app/mapa/denue/

29. Instituto Nacional de Estadística, Geografía e Informática (INEGI) (2009) Censos Económicos. México. Recuperado el 6 de marzo de 2018 de https://www.inegi.org.mx/app/saic/
30. Instituto Nacional de Estadística, Geografía e Informática (INEGI) (2014) Censos Económicos. México. Recuperado el 6 de marzo de 2018 de https://www.inegi.org.mx/app/saic/

31. Instituto Nacional de Estadística, Geografía e Informática (INEGI) (2013). Estadísticas a propósito de la industria de papel. Recuperado el 11 de agosto de 2019: http://internet.contenidos. inegi.org.mx/contenidos/productos/prod_serv/contenidos/espanol/ bvinegi/productos/estudios/economico/a proposi_de/Papel.pdf

32. Instituto Nacional de Estadística, Geografía e Informática (INEGI), Índice de precios consultado 11/08/2019. Recuperado el 11 de agosto de 2019: https://www.inegi.org.mx/temas/inpp/

33. Vargas-Ovando, L. J. (2015) Valor económico del agua en la industria manufacturera chilena: Enfoque de productividad marginal de factores [Tesis Doctoral], Universidad de Concepción, Concepción, Chile. Recuperado el 23 de julio de 2019 de: http:// repositorio.udec.cl/bitstream/handle/11594/1878/Tesis_Valor_ economico_del_agua_en_la_industria_manufacturera_chilena. pdf? sequence $=1 \&$ isAllowed $=\mathrm{y}$

Publisher's Note Springer Nature remains neutral with regard to jurisdictional claims in published maps and institutional affiliations. 